\title{
USING MOBILE APPLICATIONS DURING THE ENGLISH LANGUAGE LEARNING IN THE HIGHER EDUGATIONAL MILITARY ESTABLISHMENTS
}

A The paper determines the urgency of implementing innovative technologies in teaching foreign languages of higher educational military establishments. The efficient usage of technical means of training is substantiated as far as scientific process put in front of us challenges that are necessary to transform into friendly tools to provide learners with chances to obtain knowledge that is enough to participate fruitfully in professional discussions with Ukraine's international partners. Providing foreign language training for future officers of the Armed Forces of Ukraine to participate in international operations with cadets of military higher education institutions is an extremely urgent problem that requires prompt handling at both the theoretical and practical levels. To promote interactive cooperation synchronous communication tools that are actually the Internet tools that allow to communicate in real time (chat, video chat and audio chat). Examples of tools that enable synchronous communication via chat and voice communication are not only Skype or Viber, various ones provide the ability to establish instant voice and video connection with engaging in conveying learning material, accompanied by various types of individual, whole class and pair activities anywhere in the world. Moreover, online platform is secured enough as far as a teacher can create your own list of friends and invite them to a one-on-one chat or organize a conference, a so-called group chat. Therefore, the particularities, possibilities and prospects of using innovative technologies in foreign languages' training are considered in the paper. With the growing role of foreign language training future officers, the need to apply modern information technology education in the practice of higher educational military establishments is relevant today. Further analysis has confirmed the actuality of executing interactive technologies and mobile applications of teaching discipline «Foreign language for professional purpose».

Key words: innovative technologies; teaching foreign languages; teaching a foreign language; mobile applications; the higher educational military establishments

(5) Пасічник Сусанна, Сергієнко Тетяна, Маньковська Христина. Використання мобільних додатків під час вивчення англійської мови у вищих військових закладах.

Визначено актуальність упровадження інноваційних технологій у викладання іноземних мов вищих військових навчальних закладів. Обгрунтовано ефективне використання технічних засобів під час навчання, оскільки науковий прочес ставить перед нами завдання, які необхідно перетворити на дружні інструменти, щоб надати курсантам можливість отримати знання, достатні для плідної участі у професійних дискусіях з міжнародними партнерами України.

Забезпечити відповідний рівень іншомовної підготовки, зокрема англійської професійного спрямування офічерам Збройних Сил України для участі в міжнародних заходах є надзвичайно актуальною проблемою, яка потребує оперативного вирішення як на теоретичному, так і на практичному рівнях. Тому в роботі розглядаються особливості та перспективи використання інноваційних технологій у навчанні іноземних мов. Подальший аналіз підтвердив актуальність упровадження інтерактивних технологій і мобільних додатків у навчальній дисципліні «ноземна мова за професійним спрямуванням».

Ключові слова: інноваційні технології; навчання іноземним мовам; навчання іноземної мови; мобільні додатки; вищі військові заклади

Pasichnyk Susanna, Candidate of Public Administration, Professor of Foreign Languages and Military Translation Department, Hetman Petro Sahaidachnyi National Army Academy, Ukraine

Пасічник Сусанна Михайлівна, кандидатка наук з державного управління, професорка кафедри іноземних мов та військового перекладу, Національна академія сухопутних військ імені гетьмана Петра Сагайдачного, Україна

E-mail: suzanna111979@yahoo.com 


\section{ПРОФЕСІЙНА ОСВІТА}

Serhiienko Tetiana, Candidate of Pedagogical Sciences, Assistant Professor of Foreign Languages and Military Translation Department, Hetman Petro Sahaidachnyi National Army Academy, Ukraine

Сергієнко Тетяна Миколаївна, кандидатка педагогічних наук, доцентка кафедри іноземних мов та військового перекладу, Національна академія сухопутних військ імені гетьмана Петра Сагайдачного, Україна

E-mail:tanyasergh@gmail.com

Mankovska Khrystyna, Assistant of Foreign Languages and Military Translation Department, Hetman Petro Sahaidachnyi National Army Academy, Ukraine

Маньковська Христина Іванівна, викладачка кафедри іноземних мов та військового перекладу, Національна академія сухопутних військ імені гетьмана Петра Сагайдачного, Україна

E-mail:kferens24@gmail.com

Actuality of the problem. The urgent need of modern society for military specialists who are fluent in a foreign language in everyday life as well as in professional activities, necessitates the search for new construction methods and techniques to optimize and intensify foreign language learning, acquire new knowledge and improve language proficiency in a particular realm.

Concurrently with conventional didactic methods, the faculty have initiated the introduction of widely modern information technology into the educational process, the most fundamental of which is its computerized version.

The paper presents the analysis of peculiarities to implement information technology in the foreign language training at higher military institutions as means of intensifying the educational process and improving the quality of the mastered material.

Recent researches. Investigation of recent researches as well as publications demonstrates the evidence of a significant amount of studies in the following areas: the formation of communicative competence (O. Romanova, O. Cheremiska, etc.); innovative approaches to teaching a foreign language for professional purposes (O. Andrushchenko, I. Bashmakova, O. Plotnikova, etc.); innovative learning technologies (I. Divakova, L. Oliynyk, A. Nisimchuk, M. Papagutina, O. Plugatareva, I. Serpovska, etc.); use of information and communication technologies in the educational process (V. Bykov, Y. Bulakhova, O. Bondarenko, V. Zabolotny, G. Kozlakova, O. Mishchenko, $O$. Pinchuk and other).

The researchers as E. Polat, E. Dmitreeva, S. Novikov, T. Polilov, L. Tsvetkova and others are actively involved in the development and integration of new information technologies in the educational process; design methodology (I. Zimnya, E. Polat, etc.);

Unsolved issues. In most publications, the scholars, considering various aspects of an issue related to the latest information technologies in the educational process, note the increasing role of e-learning at all stages of the educational process and conclude that innovative foreign language teaching technologies combine interactive teaching methods with technical teaching aids (computer, multimedia, Internet) $[1, p .58]$ they share their experience in delivering multimedia conferences and creating interactive sites, offering tests for self-control that could help students determine their language proficiency levels, organize forums for learners [2, p. 37].
However, there is a lack of thorough research on the definition and prospects of utilizing information and communication technologies in the process of learning a foreign language by cadets at higher military educational institutions and therefore their further research and implementation in the system of higher military educational institutions turned to be promising one.

The objective of the paper. The issue of modern gadgets as distractors of the educational process has already possessed its podium, however the scientific process can't be terminated or suspended that is why the mentioned obstacle is necessary to transform into a facilitating tool of the language training process. The paper is dedicated to the partial study in this field.

Presentation of the main material. The introduction of modern information technologies and mobile applications in foreign language classes has a number of methodological advantages:

- increasing the efficiency of the educational process by simultaneous demonstration of theoretical language aspects along with visual aids via mobile applications and other computer equipment that enable comprehensible presentation of material;

- opportunity to teach cadets to execute mobile applications while solving educational and professional issues;

- arrangement of individual work of cadets, highlighting development of their autonomy and creativity;

- enhancing motivation of cadets due to the greater «attractiveness» of mobile applications and computer equipment, which is growing due to multimedia effects;

- development of visual thinking, motor and verbal skills of cadets;

- generation of skills to deal with information.

In the field of foreign language teaching the majority of professionals consider communicative language teaching as an innovation.

Thus, the methodological content of modern foreign language classes should be communicative and the formation of students' appropriate communicative competence, which is defined as the ability to effectively apply knowledge in various conditions of professional communication as well as certain social situations [3, p. 65].

Foreign language teachers face the problem of finding ways to increase the cognitive interest of cadets in language learning, consolidating their positive motivation to learn. 
One of the ways to handle the mentioned issue is to utilize mobile applications and computer programs both in foreign language classes and during self-preparation periods.

Software and mobile applications used in foreign language classes, of course, contribute to the improvement of such traditional teaching methods as:

- verbal ones: story, conversation, explanation, etc. where the main means of learning is a living word that is easily combined with other means of learning.

Allows for a short period of training through the use of mobile applications and applications allows you to supplement it with textual information on the screen, accompanied by reading the speaker.

It is possible to repeat many times. Hyperlinks allow you to quickly find the information you need;

- practical: exercises, various educational tasks that are used for practice and, ultimately, the acquisition of planned skills is through the processing of practical material through the use of information technology, while the tasks have a differentiated nature, the number of organizational moments decreases;

- control methods (Testing of acquired theoretical and practical knowledge, acquired skills and abilities), where test or control tasks are used, True / False questions, communicative situations when using computer programs and mobile applications speed up the evaluation of results and make them many times more effective, there is an opportunity for rapid self-assessment.

But how should we combine mobile applications and English language learning in the classes as well as off-duty hours? Nowadays more and more teachers of both secondary schools and higher educational institutions arrange their classes' activities with such devices, or, to be more exact, different mobile applications. They indeed are available for free. Let consider some options to use mobile applications.

1. Social network applications could help us create class groups: divide groups of our cadets according to language levels: one group for beginner and elementary levels, next for pre-intermediate and intermediate levels etc. It gives us the opportunity to order the material by the level of difficulty. The teacher can send short educational videos (from YouTube up to 3mins) to the groups, share the task or opinion with students and get them to contribute their own comments on videos.

2. Smartphone helps to organize education in the microlearning format: watch grammar video on mobile screen during the travelling in transport or other similar situations. It is possible to do some grammar exercises online also.

3. The mobile dictionary applications can facilitate the process of translation, on top of this proper pronunciation of words are provided using advanced speech engines.

4. Warming up, brainstorming or even testing can be fascinating activities with using such online tools as Kahoot, Quizzlet, Surveymonkey that are easily accessible with mobiles, however they should be connected to the Internet. In this case, an issue of evaluation is quite challenging, on the other hand, an objective of the education process is not only to rate but to motivate learners as well as to increase the level of language competence in order to enable cadets to operate in the English speaking environment. The English-speaking environment is to be established with the help of the mobiles as far as all platforms and online tools are mostly in English. Moreover, the cadets can be assigned creative tasks such as composing quiz or survey based on learned material.

5. Currently, more and more tools are emerging that can be used in addition to the above, both synchronously and asynchronously. Among them is the Padlet, whose functions allow you to develop both tasks for the exchange of information submitted for pre-processing, and when conducting Brainstorming at the beginning of the development of a particular topic, or for reference. The author develops the question using the available features, as the program has both free and paid features, and then provides links to students and they do not need to install this application.

To create presentations, feedback surveys, we use the Mentimeter application, a fairly simple resource and helps to diversify synchronous learning, students are not required to install the application, just use the code provided by the author by visiting menti.com.

6. A vast variety of authentic sources to enhance listening skills are available with the downloading of a number of applications, for instance: learning English with the BBC, 6-min English etc. They provide brief news reports or just dialogues on various up-to-date topics with the explanation of key vocabulary. In addition, the topics are regularly updated, that is why they remain actual and catchy.

7. Reading is as essential as other skills to master a foreign language. Some cadets do not understand the exact meaning of words and their vocabulary is quite poor to read complicated, in particular authentic articles without dictionaries. But constant glancing into the dictionary destroys the pleasure of reading and leads to the habit of translating the text into Ukrainian; it prevents the cadets from thinking in English.

One of the ways out in this case is that a teacher can propose them to read in the following sequences: the first time it's reading for pleasure (without stopping and trying to understand literally). The second time is reading for a context understanding (trying to understand unfamiliar words with the help of known ones). And the last one is reading for the accuracy - looking up unclear words in the dictionary. At the same time the process is proactive; searching in an online dictionary or translator is useful, because cadets are typing words manually. The mobile dictionary will help them to find an unfamiliar word, read its English definition or find synonyms to explain the meaning of an incomprehensible word to the teacher.

8. Mobile test editors allow making a summary. This is not an easy task. So that teacher should restrict our cadets in a number of symbols $(90-120)$. The summary can be composed ac- 


\section{ПРОФЕСІЙНА ОСВІТА}

cording to the text read, the studied topic, even as the entire lesson conclusion.

9. To improve the cadets' Speed Chat skills the teacher can Send to cadets a picture on a phone and give them a task. If this is an image of a person - it has to be described, if it is the screen of the city map - then cadets have to "tell the tourist» how to get the point marked on the map, if the cadet gets the photo of a cafe menu - he needs to order the dish to the waiter, if it is the photo of the bookshelf - ask the seller about the book of interest from this shelf, if the view from the window... sometimes, let them guess what they should do. The teacher can come up with any tasks; the main thing is to respond quickly. It would be a good choice of warming up at the beginning of the class with messages using.

Research results. So the utilization of mentioned tools proved to be efficient especially while the study relates to an aspect of motivation. Moreover, it turned to have discovered some educational applications that provide such activities as matching or multiple choice types. On one hand they can help cadets to check their skills, on the other hand for teachers to evaluate cadets' achievements.

To date, there is no longer a problem with the limited number of hours devoted to the study of a foreign language by cadets of higher education institutions in the classroom, but a significant part of the educational work cadets must do independently.

The new material presented by the teacher in the classroom needs to be thoroughly consolidated during the individual training of cadets, which can also take place in regular classrooms or in transport via mobile devices.

For this purpose, a didactic course in a foreign language was created, which provides gradual mastering of the language material of the professional direction, its actualization, constant control, etc.

Indeed, mobile applications and computer programs can provide feedback and performance monitoring with timely error correction and more.

Conclusions. Thus, the current educational process in higher military educational institutions is to provide cadets with the opportunity to work individually, develop creative abilities and talents, realize their full creative potential, give full free- dom in solving professional issues and tasks, to allow «deviate» from conventional algorithms, ways to obtain ability of critical thinking in order to awaken your inner mental activity.

The application of modern information technology in the classroom, undoubtedly contributes to their efficient learning of foreign languages by cadets of higher military educational institutions.

Prospects for further exploration. The proposed research gives the opportunity to implement the suggested conclusions in the further educational process of language training in order to analyze the efficiency of the mentioned tools in order to enhance the quality of the knowledge which are obtained by the military learners. Taking into consideration the abovementioned facts, it should be noted that the implementation of information technology significantly expands and diversifies the foreign language curriculum at the academy.

This organization of the educational process significantly increases the motivation of cadets, encourages them to work individually on mastering the discipline, self-analysis and selfcontrol, develops the need for future professionals in selfeducation.

\section{References}

1. Andrushchenko, O. (2012). English-language professional communication with the implementation of IT. Demo lesson, 1, 56-60.

2. Clijsters, W., \& Verjans, M. (2002). Olyfran.com: pour jouer avec le fransais. FDLM - Cle international - Paris, 323, 37-38.

3. Gapon, Yu. A. (2000). The utilization of computer technology at the stage of introducing new material in the system of intensive foreign language learning. Foreign languages, 2, 26-28.

4. Holkovska, I. L., \& Holkovskyy, Y. R. (1999). Problems of future professional experts. In Ways and education problems entering Ukraine into the world educational space: intern. science. conference (pp. 127-131). Vinnitsa.

5. Pometun, O., \& Pirozhenko, L. (2003). Interactive learning technologies. Demo lesson, 3-4, 19-32.

6. Romanova, O. (2012). Model of formation of professional competence of a teacher. Pedagogy, 2, 63-70.

7. Serpil, Meri-Yilan.(2020). Task-based languagelearning through digital storytelling in a blended learning environment. conference: e-Learning Symposium At: Southampton, UK. URL: https://www.researchgate.net/publication.

8. The concept of distance education in Ukraine. URL: http://www.osvita.org.ua/ distance/pravo/00.html

9. Relations with Ukraine. URL: http://www.nato.int/cps/en/natohq/topics_49206

10. International conference materials: COVID-19 Defence Education. URL: https:// www.nato.int/DEEP

Дата надходження до редакиіі авторського оригіналу: 07.12.2021 